\title{
V13 Desenvolvimento e validação de metodologia para determinação de ácido siálico no polissacarídeo meningocócico C por cromatografia iônica
}

\author{
Luiz Claudio Ferreira Pimentel ${ }^{1}$, Magda Majores ${ }^{1}$ \\ ${ }^{1}$ Bio-Manguinhos, Fiocruz, RJ
}

Introdução: A cromatografia por troca aniônica em pH elevado acoplada com detecção amperométrica pulsada (HPAEC-PAD) é uma técnica cromatográfica, que pode ser aplicada à análise de carboidratos. A utilização de $\mathrm{pH}$ muito básico promove a dissociação de carboidratos hidroxílicos, convertendo-os de espécies neutras em aniônicas. Assim como outras técnicas cromatográficas, a sua quantificação pode ser feita por padronização interna, externa ou fortificação. O PSC, polissacarídeo meningocócico sorogrupo C é constituído de unidades repetidas do ácido siálico conhecido por ácido $\mathrm{N}$-acetilneuramínico (Neu5Ac). Este polissacarídeo é utilizado nas formulações da vacina meningocócica $\mathrm{C}, \mathrm{AC}$ e ACW, sendo todas produzidas por Bio- Manguinhos.

Objetivo: Desenvolver uma metodologia alternativa para a quantificação de ácido siálico no polissacarídeo Meningocócico sorogrupo $\mathrm{C}$ por HPAEC-PAD.

Metodologia: A etapa inicial do desenvolvimento do método consistiu no estudo da melhor condição de hidrólise do polissacarídeo em questão, devido à suscetibilidade do ácido siálico liberado em meio ácido. Esta condição foi alcançada com ácido clorídrico $1 \mathrm{M}$ por 30 minutos a $80^{\circ} \mathrm{C}$ e, a fim neutralizar o ácido clorídrico utilizado, houve uma posterior adição quantitativa de hidróxido de sódio $1 \mathrm{M}$. As condições cromatográficas foram otimizadas com a utilização de uma coluna carboPac PA10, fase móvel com composição de $100 \mathrm{mM} \mathrm{NaOH/}$ $\mathrm{NaOAc} 100 \mathrm{mM}$ em modo isocrático, detetor de ouro e a utilização de uma waveform para ácidos siálicos (triple potential) sugerida pelo fabricante. $O$ desenvolvimento do método resultou em uma análise de 10 minutos por injeção com economia de padrão e menores limites de quantificação. Os resultados foram confrontados com o método atual por espectrofotometria (Svennerholm) cujo princípio se baseia na hidrólise do polissacarídeo com liberação e conversão do ácido siálico para reação com cobre (II) e resorcinol, formando um composto colorido após aquecimento, que, após ser extraído com solvente orgânico, é medido espectrofotometricamente.

Resultados: O método desenvolvido foi validado e encontra-se de acordo com a RE n899 de 2003, da ANVISA. Foram analisados cinco lotes diferentes de PSC através das duas metodologias e o teste ANOVA demonstrou não haver diferenças significativas entre os 
resultados obtidos pelos dois métodos ( $F$ cal $=0,64<F c r i t=5,32$ ) com 95\% de confiança.

Conclusão: De acordo com os resultados obtidos na validação e na comparação entre os lotes pelas duas metodologias, conclui-se que o método por HPAEC-PAD pode ser utilizado com segurança como um método alternativo ou na substituição do método espectrofotométrico. Ele é mais vantajoso por utilizar menor quantidade de padrão, ácidos inorgânicos mais diluídos, menor limite de quantificação, menor tempo de análise e por não utilizar solventes orgânicos.

Palavras-Chave: Polissacarídeo, Ácido Siálico, HPAEC-PAD 